\title{
An Exploratory Study of Forgiveness' Place into the Interpersonal Conflicts of Pre-teenagers
}

\author{
Maria Isabel da Silva Leme ${ }^{1}$ \\ Laura Carrasqueira Bechara ${ }^{1}$ \\ Mariana Kfouri ${ }^{1}$ \\ ${ }^{1}$ Universidade de São Paulo, São Paulo, SP
}

\begin{abstract}
Forgiveness, besides being a controversial issue among researchers in terms of its nature, has not been studied in younger age groups, and neither related to the conflict situations faced by this population. This study aimed to fill this gap, seeking relationships among pre-teens' strategies to solve conflicts and forgiveness, as well their conceptions about the act and possible relationships with characteristics like religion practice, gender. Therefore, we collected information about pre-teens' conflict resolution strategies as well religion, the types of situations and persons considered forgivable, and regarding themselves, when and how would they ask for forgiveness. It was found that, although the participants have accurate concepts of forgiveness, the occurrence of such an act in terms of situations and circumstances considered forgivable is not yet related to their conflict resolution strategies. On the other hand, some results related to forgiveness contribute to a better understanding of preteens' interpersonal conflicts.
\end{abstract}

Keywords: forgiveness; conflicts; pre-adolescents; religion

\section{Estudo Exploratório sobre o Lugar do Perdão nos Conflitos Interpessoais de Pré-Adolescentes}

\begin{abstract}
Resumo
O perdão, além de objeto de controvérsia entre pesquisadores, não tem sido estudado em amostras mais jovens e relacionado aos conflitos enfrentados por esta população. Esta pesquisa visou a preencher essa lacuna, buscando relações entre estratégias de resolução de conflitos de pré-adolescentes e ocorrência de perdão, bem como suas concepções sobre o ato e sua associação com religião, sexo, etc. Foram coletados por meio de questionários aplicados em 291 pré-adolescentes dados sobre religião praticada, resolução de dez conflitos interpessoais, tipos de ofensa consideradas perdoáveis, com que pessoas, e com relação a si próprio, quando pediria perdão e como procederia. Verificou-se que embora tenham concepções pertinentes sobre o perdão, a ocorrência de tal ato em termos de situações e circunstâncias consideradas perdoáveis ainda não tem relação com as estratégias de resolução de conflito escolhidas. Por outro lado, alguns resultados relacionados a concepções sobre perdão contribuem para a melhor compreensão dos conflitos interpessoais de pré-adolescentes.

Palavras-chave: perdão, conflitos, pré-adolescentes, religião
\end{abstract}

Estudio Exploratorio sobre el Lugar que ocupa el Perdón en los Conflictos Interpersonales de Pre-adolescentes

\begin{abstract}
Resumen
El perdón, además de tema de controversia entre investigadores, no ha sido estudiado en muestras más jóvenes, y tampoco relacionado a los conflictos enfrentados por esa población. Esta investigación pretende llenar este vacío, buscando relaciones entre las estrategias de solución de conflictos entre pre-adolescentes y ocurrencia de perdón, así como concepciones sobre el acto y su asociación con religión, sexo, etc. Fueron recogidos, por medio de un cuestionario aplicado en una muestra de 291 pre-adolescentes, datos sobre religión practicada, solución de diez conflictos interpersonales, tipos de ofensas consideradas perdonables, con qué personas, con relación a sí mismos, cuándo pedirían perdón y la forma en que procederían. Se verificó que aunque tengan conceptos pertinentes sobre perdón, la ocurrencia de tal acto en términos de situaciones y circunstancias consideradas perdonables, todavía no tiene relación con las estrategias de solución del conflicto elegidas. Por otro lado, algunos resultados relacionados a conceptos sobre perdón contribuyen para una mejor comprensión de los conflictos interpersonales de pre-adolescentes.

Palabras-clave: perdón; conflictos; pre-adolescentes; religión
\end{abstract}

The study to be reported is part of a broader research program developed over more than a decade, about social and affective learning transference, studied through the resolution of children's and pre-teenagers' interpersonal conflicts. This kind of occurrence is considered appropriate to study this learning stage because it consists of a problem situation that demands the recuperation and adaptation of previous knowledge to solve the impasse created by the situation of opposition among those who are involved, which, in turn, unleashes negative affections that may interfere with decision making (Blanchette, 2014).

To carry out these studies, we have employed an open instrument containing 10 situations of interpersonal conflict caused by some type of opposition, or even aggression perpetrated by friends, colleagues or 
parents, whose intention is not always explicit. After each description, the participant is asked to describe what he or she would do as a victim of the type of situation described above (Leme, 2004, Leme, 2006, Leme, Carvalho and Joveleviths, 2012, Leme and Carvalho, 2014).

A very consistent result during these years of research with this instrument, which motivated the realization of the present study, has been the extremely rare mention of the granting of forgiveness in the participants' responses. This is because what has been verified is the prevalence of the participants' responses indicating avoidance or lack of reaction to solve the described impasse. Next, responses are observed indicating violent reaction, that is, the search for a solution through the use of force or coercion. Third, there is a prevalence of responses that are considered mixed, combining avoidance or lack of resolution with some kind of veiled aggression, such as planning to break up the relationship with the other protagonist, who is the cause of the conflict. Only in fourth place do the better responses to the maintenance of the relationship appear, seeking conciliation of interests through negotiation, and more rarely, the acquittal of the antagonist via pardon (Leme, 2004, Leme, 2006, Leme, Carvalho and Joveleviths, 2012, Leme and Carvalho, 2014).

When forgiveness is explicitly mentioned by the participants of the mentioned researches, it is usually associated to the lack of reaction in situations where the other protagonist's intention is given the benefit of the doubt. A good example of this kind of situation in the instrument used is the description of conflict caused by a small child who would throw a ball at the participant's head. The participants inform they would not react to that situation, once "a small child does not know what they do" (Leme, 2004, Leme, 2006, Leme, Carvalho e Joveleviths, 2012, Leme e Carvalho, 2014).

Therefore, when such situation of the explicit mention of the benefit of the doubt or the negotiation tries to solve the impasse is not verified, it is not possible to know what the lack of reaction means and what might come from there. This is because it could either mean that the aggressor has been forgiven, as it was mentioned in the example with the ball, or as Barnes, Brown and Osterman (2009) observed that the victim seeks self-protection from future aggressions. It may still mean revenge due to the breaking up of the relationship. The authors point out that revenge and forgiveness are elements of the same motivational system subjacent to people's answers to interpersonal offenses.
It is worth observing that revenge is conceived by several researchers as incompatible with forgiveness, since it aims at the retribution of harm to the aggressor, while forgiveness involves the deliberate abandonment of the negative feeling to which one is entitled (Fehr, Gelfand \& Monisha Nag, 2010; Struthers, Eaton, Santelli, \& Uchiyama, 2008; Rizkalla, Wertheim \& Hodgson, 2008; Davis \& Gold, 2011; Eaton, \& Struthers, 2006; Santana \& Lopes, 2012; Abreu, Moreira \& Rique, 2011).

Still regarding the definition of forgiveness, Abreu et al. (2011), observe that there are more points of disagreement among researchers than agreement, with more frequent consensus on what does not consist of forgiveness than on the contrary. Santana and Lopes (2012), agree with this view, reporting that the study of forgiveness is recent, both in the world and in Brazil, where it began only about twenty years later, in the years 2000, in the context of studying social skills. However, they point out that there is some consensus in the conception that forgiveness is a conscious choice to change the affective and cognitive dimensions of the offender. According to these authors, the main points of disagreement are the nature of the phenomenon, whether it is intra or interpersonal, the type of process involved, the transformation of negative feelings and thoughts into positive ones, or just the abandonment of the negative ones, and the probability of occurrence. Under this perspective there are frequent controversies about the relationship between forgiveness and reconciliation, as well as changes in feelings throughout the process. According to Mc Cullough, Pargament and Thorensen, (2000), it is probable that the little interest of Psychology in studying forgiveness can be explained through the relation of the phenomenon towards religion, a relationship that is devalued by social sciences. However, it is worth mentioning that Enright (2002), one of the pioneers in the study of forgiveness, reports that what motivated him to study the phenomenon was to understand that his elucidation could meet the real needs of people, changing their lives.Fehr, Gelfand and Monisha Nag (2010), point out that there is little integration among researchers due to the recency of the study of the phenomenon and the lack of consensus among researchers.

To contribute to this integration, Fehr et al (2010), performed a meta-analysis of 175 studies, verifying that the following situational relations can be established: an apology by the offender and the granting of forgiveness; the attribution of responsibility to the offender and the absence of pardon; attribution of intent to the offender 
and absence of pardon; rumination and absence of forgiveness. They also verified that relationships among dispositional characteristics and the concession of forgiveness can be established: the victim's friendliness, as well as their capacity for perspective. In the affective plan, empathy and the concession of forgiveness, feelings of anger and absence of forgiveness stand out. The latter is explained by Eaton and Struthers (2006), who verified that the admission of responsibility and the manifestation of repentance by the offender diminishes the victim's anger, increasing the probability of granting forgiveness.

However, as Leunissen, Cremer, Folmer, and Djike (2013), verified, not always are these conditions favorable to forgiveness. By analyzing differences between the victim and the offender at resolving conflicts, they found that apology, in the view of the victim, is necessary so that their anger can cease. On the other hand, the aggressor would tend to apologize more when the transgression was not intentional because in some cases, after intentional aggression, they come up with a process of rationalization about the act, incompatible with the admission of responsibility, which would arouse more anger in the victim. It should also be considered that Abreu et al. (2011), point out that apology and reconciliation are not indispensable to the granting of forgiveness, for example, for deceased offenders. However, they found that children associate the two processes, probably because reconciliation represents forgiveness more concretely. In addition, it should be considered that if reconciliation does not necessarily stem from the forgiveness process, the latter is essential for reconciliation to happen (Rique et al., 2011).

As for the object of this research, the relationship between the conflict resolution strategy and forgiveness, Rizkalla et al. (2008), found that adults considered to be good conflict solvers, not only showed greater perspective and tendency toward the conciliation of interests, needed for a satisfactory solution, but also, as verified above, greater willingness to forgive. These good solvers are people who do not allow themselves to be dominated by emotion, which allows them to assess the situation more objectively, as well as to mend emotions. In this regard, Abreu et al. (2011), mention researchers who consider that forgiveness is important for children's cooperation and development of skills to solve conflicts.

However, the propensity to solve issues through confrontation is related, according to Riskalla et al. (2008), to the greater difficulty in dealing with a negative emotion, which, in turn, makes it difficult to examine the situation more objectively. An example of such a trend would be the attribution of offense to a stable disposition of the offender (Davis \& Gold, 2011), which increases the expectation of recurrence, reducing the likelihood of empathy to be aroused.

Regarding the development of these relationships between forgiveness and personal and situational characteristics in ontogenesis, Baneerjee, Benett and Luke (2010), found that children between the ages of 4 and 9 consider that excuses and explanations avoid not only punishment, but improve the image of the transgressor. However, the excuses have more positive value because they are seen as motivated for the other and the explanations as self-protection. Nevertheless, only older children have shown that the explanation given for not taking responsibility could even harm the image of the offender when they should be apologizing. Researchers point out that the cognitive developmental and socialization processes that lead to this understanding need to be clarified in future researches.

Motivated by a similar finding, the lack of studies on forgiveness among Brazilian children, Abreu et al. (2011), investigated how children six to eight years old solved a dilemma involving forgiveness. They found that the majority $(60 \%)$ were unable to define forgiveness, and among those who succeeded, only a minority was in favor of granting it, although they demonstrated that they were able to put themselves in the other person's shoes showing that this capacity is not enough for forgiveness. They also showed an understanding that time is an ally of forgiveness, in the sense that anger diminishes as time goes by. It was further observed that children considered that forgiveness was related to the need to repair and compensate for the transgression committed and should be preceded by an apology. The act of apologizing was seen as a reparation of moral character, when the damage cannot be materially repaired.

Finally, some other important factors are worth mentioning, because they also alter the probability of occurrence of forgiveness, such as religion and closeness to the offender. As for religion, Gouveia et al. (2009), report that the practice of Catholicism would be related to the greater disposition to forgive, since the values defended would induce to this reaction. This would be an indication that there is a social motivation involved in the act of forgiving, that is, forgiveness refers to something that is socially valued. The authors verified that, in addition to the aforementioned 
proximity between the protagonists favoring forgiveness, the commitment and satisfaction with the relationship influence it too. The researchers did not verify gender differences in the greater willingness to forgive, but in age, whose progress increases the probability of granting forgiveness, which was also verified by Schleien, Ross and Ross (2010).

Finishing the review of the found researches on forgiveness, it can be concluded that the act is a process of change of feelings towards the perpetrator (Santana and Lopes, 2012), which is favored by the manifestation of repentance, lack of intention and request of apologies by the offender (Fehr et al., 2010, Leunissen et al., 2013). The proximity to the perpetrator of the offense and the passing of time are factors that favor the granting of forgiveness, as well as age, religious practice and personal characteristics as the perspective-taking ability (Gouveia et al., 2009). On the other hand, the scarcity of researches aimed at clarifying the variables that intervene on forgiveness during the development (Baneerjee et al., 2010), points to the need for further investigations to establish whether pre-adolescents, good conflict solvers, are more prone to forgiveness like adults are (Riskalla et al., 2008). It will still be possible to evaluate whether the lack of conflict reaction, which we recognized in previous studies (Leme, 2004, Leme, 2006, Leme, Carvalho and Joveleviths, 2012, Leme and Carvalho, 2014), is related to the beginning of the forgiveness process and which situations are more favorable to the granting and maintenance of the relationship in this age group. Given the impact that these processes may have, not only on the continuity of the relationship between the transgressor and the victim, but also on the environment of coexistence among young people (Rodrigues, Dias \& Freitas, 2010), we consider it important to verify how forgiveness relates to different conflict resolution strategies, which as far as we have checked, has not yet been investigated.

In this respect, it is important to specify that the strategies identified in our studies (Leme, 2004, Leme, 2006, Leme, Carvalho and Joveleviths, 2012, Leme and Carvalho, 2014), express two basic forms of conflict resolution: violent, and non-violent confrontation and the absence of coping characterized by avoidance or escape. The pacific confrontation can be characterized by the negotiation or conciliation of interests, and the violent by aggression. Deluty (1979), one of the first researchers to investigate this phenomenon, called the pacific confrontation, assertive strategy. Such strategy would be the most desirable, for taking into account the other person's point of view, reconciling it with one's own opinions and rights. According to what the author proposed, the peaceful strategy, such as conciliation, demands willingness to listen to the other, for example, the desire to clarify the reasons for what caused harm. Because of these characteristics, it is reasonable to assume that it is probably the strategy that is more related to forgiveness and favors it the most. Deluty (1979), also identified another pacific strategy that he called submissive, which is characterized by the absence of reaction, expressed in evasion or avoidance, which, as already pointed out, has prevailed in the samples studied by us, and that we qualify as lack of confrontation (Leme 2004, Leme, 2006, Leme and Carvalho, 2012). Deluty (1979), also investigated another form of confrontation, not pacific, because it aims at solving the impasse through physical or verbal coercion, better known as aggression. As previously mentioned, we have found in our research that strategies can be combined into mixed strategies, such as aggressive submission, recurrent, or submission with conciliation (Leme, 2004, Leme, 2006, Leme and Carvalho, 2012). As for the variables that have already been identified as important in the most prevalent use of a strategy over the others, it is verified that age is one of them (Rodrigues et al., 2010), since both development and experience intervene on the process. Development is important because it allows dealing with cognitively more complex situations such as conflict, which involves many dimensions to be coordinated among themselves for the decision making, such as the intention of the offender, damage assessment, possible reactions and risks involved. The experience is also very important because it allows the abstraction of similar situations in schemes, which help in the interpretation of the situation and in the decision making concerning the reaction, facilitating the process. Sex is another relevant variable in conflict resolution because aggression is more tolerated in men than in women, already in the beginning of socialization (Leme, 2004). The environment in which this socialization occurs is also an important variable, since exposure to violence represents a risk at the beginning of life, when the first social interaction schemes are being formed, and the absence of peaceful resolution models hampers their learning (Posada \& Parales, 2012). Likewise, the culture in which socialization takes place plays an important role, due to its greater or lesser tolerance to violence as a form of resolution. Individualist cultures tend to tolerate confrontation more than collectivists. Collectivists 
tend to condemn violence in order to preserve group harmony (Bergeron \& Schneider, 2005).

In short, the study of forgiveness can shed light on several important aspects of resolving interpersonal conflicts, such as the influence of assessing the severity of offenses, the offender's identity, their intent, and others. The relationship of forgiveness with the ability to solve conflicts well verified among adults, highlights the importance of investigating whether the same occurs among pre-adolescents, and if so, in what type of conflict, with which protagonist. According to Macedo and Sperb (2013), pre-adolescence, according to the Pan American Health Organization, is the age group that goes from 9 to 12 years of age in girls and from 10 to 13 in boys. Still according to the Pan American Health Organization, this is the most appropriate period to be addressed by health promotion and prevention programs, since the behaviors that undermine it have not yet begun or are easier to be changed. The authors also verify that in Brazil the age range of 9 to 13 years has been little investigated in Psychology. It is also considered important to investigate the influence of other variables on the tendency to forgive, such as a previous experience with the act, sex, practice of religion and conceptions regarding forgiveness.

Therefore, the objective of the present research is to investigate, in an exploratory nature, if there is a relation among willingness to forgive, conceptions of forgiveness and conflict resolution strategies reported by pre-adolescents. The hypothesis is that pre-adolescents who report conciliatory conflict resolution strategies, who consider the right of all involved, will present a greater tendency to forgive and more adequate conceptions about forgiveness than pre-adolescents who report coercive or avoidant strategies. In this sense, it is also an objective to verify if there is greater willingness to forgive and more appropriate conceptions of forgiveness among female pre-adolescents whose resolution strategies have proved more conciliatory in previous researches. Finally, based on the relationships pointed out in the revised literature, it is expected to verify greater willingness to forgive and more appropriate conceptions regarding the act among Catholics.

\section{Method}

\section{Participants}

A total of 165 fifth, sixth, and seventh grade students from a private religious school located in the eastern part of the city of São Paulo and 126 same level students from a lay private school located in the same region participated in the study. The participants' ages varied between $10(28 \%)$ and 15 (1.5\%) years old; 12 -year-old participants formed the largest contingent of students $(32 \%)$. As far as gender was concerned, $50.5 \%$ of the participants are female and $49.5 \%$ male. Of the total number of students in the two schools, $81.9 \%$ stated that they practiced some religion, and the catholic religion was informed by $61.6 \%$ of this contingent. The evangelical religion was the second most frequent $(16.9 \%)$ in the sample, and the third, spiritism. Differences in the frequency of each religion were observed among schools; the catholic religion was the most frequent in the religious school $(71.8 \%$ versus $46.6 \%$ ), whereas evangelical and spiritism were more frequently found in the lay community $(20.5 \%$ evangelicals in the lay school to $14.5 \%$ in the religious school, $26.1 \%$ declared themselves spiritists in the lay school to $6.1 \%$ in the religious school). Because this was a convenience sample, two other differences were verified in addition to those related to the type of religion practiced already mentioned. It seems that the socioeconomic level of the students of the lay school is higher than that of the students of the religious school. In addition to the tuition fees of the lay school being about 35\% higher than in the religious school, the latter grants scholarships to students in need. And finally, in the lay school, the classes are about $20 \%$ less numerous than in the religious school.

\section{Instruments}

To reach the objective of verifying the relation between strategies of resolution and a tendency to forgive, as well as conceptions and attitudes towards forgiveness, an open questionnaire developed and given by Deluty (1979), was used. The questionnaire presents ten descriptions of hypothetical conflict situations, at the end of which the participant is asked to answer what they would do if they faced such opposition, or even aggression from parents, friends or colleagues as described there. Thus, the instrument evaluates the resolution strategy used to solve the conflict, based on the conduct specified by the participant, which as previously described, is categorized according to the type of confrontation, peaceful or coercive, or non-confrontation. Open questions about the religion practiced, experience of forgiveness and revenge, and what would have occurred, were added to the questionnaire. Closed questions about conceptions of forgiveness, elaborated based on the results found in the literature review, were also added. 
The questions elaborated to evaluate the relation of the disposition to forgive with the strategies of conflict resolution consisted of seven sentences describing the same offenses occurred in the conflicts described in the questionnaire. The participant should indicate at the end of the same whether he would forgive that offense. This information was complemented by four other issues, also closed in alternatives. The first, gathered a group of nine statements to be labeled as true or false, addressing the participant's feelings and actions after suffering various types of offense, as well as their reasons for forgiveness. Another issue to be assessed involved a set of affirmations addressing the frequency of the participant's feelings and attitudes after granting forgiveness. The last two questions asked for information about situations in which the participant would be willing to ask for forgiveness, and also in which situations they would expect to be forgiven, stating yes or no. All questions were elaborated based on what the literature identified as relevant for the granting or not of forgiveness, such as antecedent events, perception of repentance, etc., as discussed previously. These questions were pre-tested in individual interviews with six pre-adolescents, equivalent in age and grade attended, who on this occasion pointed out doubts and other problems that were corrected.

\section{Procedures}

The material was applied by two researchers in a single collective classroom session, which lasted an average of 30 minutes, and teachers were absent. The schools were informed about the goals of the research, and after agreeing to participate they obtained parental permission. Before responding to the material, participants were informed about the research objectives, guaranteed anonymity, as well as about their freedom to participate or not. The project was approved by the Research Ethics Committee, process number CAEE18268413.0.0000.5561.

The answers to the open questions were submitted to content analysis and categorization by two researchers who obtained $91 \%$ agreement in the categorizations. The procedure for assessing the reliability of the categorization consisted in firstly, categorizing the behaviors reported by the participants according to the criteria defined by Deluty (1979), that is, whether the reported behavior consisted of confronting the situation and, if so, in what way: peaceful, coercive or mixed. Next, $20 \%$ of the categorized answers obtained were drawn, and a researcher with a background in
Psychology was asked to categorize them according to the criteria stipulated for each category. The results of each researcher were compared to each other. The reliability index obtained was calculated based on the formula: number of agreements divided by the total of agreements plus disagreements multiplied by one hundred. The disagreements found were resolved by discussing the application of the criteria until the two researchers reached a consensus.

\section{Results}

\section{Conflict Resolution Strategies}

Table 1 shows the most chosen strategies to solve conflicts through the sample, both in terms of 1) absolute number of responses in the category (Freq), 2 ), proportion of each category in the total responses $(\% \mathrm{C})$ and still, 3) proportion referring to the incidence of the category in each school $(\% \mathrm{~L})$. As the mentioned table shows, the most frequent strategy in the sample as a whole was the submissive, followed by the submissive and aggressive mixed strategy. Third, the aggressive strategy, and fourth, the assertive strategy. Other strategies reported were: mixed assertive and aggressive, mixed submissive and assertive, and finally mixed assertive with submissive and aggressive, which did not reach $1 \%$.

It was observed balance between schools in the use of the two strategies, submissive (religious: $54.2 \%$, lay: $45.8 \%$ of the total of the categorized strategies) and mixed assertive and aggressive (religious: $48.9 \%$ and lay: 51.1 of the total of strategies thus categorized). There were significant differences between the two types of school in relation to the total frequencies of the three strategies, according to test $\mathrm{t}$ student at the 0.05 level $(5 \%) ; t=2.288 ; \mathrm{p}=0.026$, in the case of the aggressive strategy, the mixed submissive and aggressive, and also the assertive strategy. The magnitude of this difference was evaluated through the Cohen $\mathrm{d}$ test, calculated by using the formula $\mathrm{d}=2 \mathrm{t} / \mathrm{V}(\mathrm{gl})$, resulting in $\mathrm{d}=0.29$, considered small.

According to the chi-square test, these differences are related to the type of school in the following situations: conflict of public humiliation, in which it was found greater use of aggression in the religious school, and greater assertiveness in the lay school (x2 $=14,221 \mathrm{a}, \mathrm{df}=6, \mathrm{p}$-value $=0.0027)$. In the situation of the disorder made in the house by a friend that can result in punishment by the parents, the association was of greater submission, and aggression in the religious 
Table 1

Distribution of Frequencies of Strategies Used

\begin{tabular}{lccccccccc}
\hline & \multicolumn{3}{c}{ Religious } & \multicolumn{3}{c}{ Lay } & \multicolumn{3}{c}{ Total } \\
\cline { 2 - 10 } & Freq & \%C & \%L & Freq & \%C & \%L & Freq & \%C & \%L \\
\hline Submissive & 498 & 30.4 & 54.2 & 420 & 33.8 & 45.8 & 918 & 31.9 & 100.0 \\
Mixed submissive-agressive & 348 & 21.3 & 60.1 & 231 & 18.6 & 39.9 & 579 & 20.1 & 100.0 \\
Agressive & 346 & 21.1 & 62.1 & 211 & 17.0 & 37.9 & 557 & 19.3 & 100.0 \\
Assertive & 280 & 17.1 & 58.9 & 195 & 15.7 & 41.1 & 475 & 16.5 & 100.0 \\
Mixed assertive-agressive & 114 & 7.0 & 48.9 & 119 & 9.6 & 51.1 & 233 & 8.1 & 100.0 \\
Mixed submissive-assertive & 50 & 3.1 & 44.2 & 63 & 5.1 & 55.8 & 113 & 3.9 & 100.0 \\
Mixed assertive Submissive Aggressive & 0 & 0.0 & 0.0 & 5 & 0.4 & 100.0 & 5 & 0.2 & 100.0 \\
Total & 1636 & 100.0 & 56.8 & 1244 & 100.0 & 43.2 & 2880 & 100.0 & 100.0 \\
\hline
\end{tabular}

school, whereas in the lay one, it was in the use of the mixed strategy of assertiveness and submission $(\mathrm{x} 2=$ $29.582 \mathrm{a}$; $\mathrm{df}=6$, $\mathrm{p}$-value $=0.000)$. In the situation of the participant being pushed out of the line in the cafeteria, the association consisted of the greater use of assertive strategies in the religious school. In this same situation it was found an association between a greater use of mixed assertive and aggressive strategies in the lay school $(\mathrm{x} 2=27,198 \mathrm{a}, \mathrm{df}=6, \mathrm{p}$-value $=0.000)$. It was also found an association of greater submission in the lay school, and mixed submissive with assertive in the religious school, in the situation of the colleague's refusal to share a piece of chocolate $(\mathrm{x} 2=12,641 \mathrm{a}$, df $=5$, p-value $=0,027)$. Finally, in the loss of a reward by one point, the association found was higher submission in the lay school $(\mathrm{x} 2=12.598 \mathrm{a} ; \mathrm{df}=5, \mathrm{p}$-value $=$ 0.027). Summarizing, the differences found are related to the type of school attended by the participant: in the lay school, there was a greater use of strategies of coping and of non-confrontation, while in the religious school, more confrontation strategies, including violent ones such as aggression, which were not found in the lay school under the same situations.

The t-test did not identify significant differences between males and females at the significance level of $0.05(\mathrm{t}=0.127, \mathrm{p}=0.899, \mathrm{df} 231, \mathrm{~d}=0.02)$. However, it is worth noting that significant associations were found between school type and gender, as well as school and grade level identified by the chi-square test. In the first case, a significant association (x2 = $12,061 \mathrm{a}, \mathrm{df}=5, \mathrm{p}$-value $=0.034$ ) was found among the differentiated use of certain strategies in each sex, restricted to the lay school. These associations occurred in the report of the use of the assertive strategy, since
$62.6 \%$ of the total answers found in this category were pointed out by female students, while $37.4 \%$ of the total was pointed out by male students, all from the lay school. Still in the lay school, within the total found of the aggressive strategy, $58.5 \%$ was pointed by male students while the rest, $41.5 \%$ was pointed out by female students. In the total of mixed assertive and aggressive responses, $60.5 \%$ of the total category was pointed out by female students, while $39.5 \%$ of male students in the lay school did the same.

No significant differences were observed between the school grades in relation to the use of strategies according to the chi-square test $\left(\mathrm{x} 2=3.219^{\mathrm{a}}\right.$, $\mathrm{df}=9$, $\mathrm{p}$-value $=0.0679)$. However, a significant association was found regarding the use of the strategy in the religious school $(\mathrm{x} 2=45.415 \mathrm{a}, \mathrm{df}=10, \mathrm{p}$-value $=0.000)$ and in the lay school $(41,972 \mathrm{~b}, \mathrm{df}=10$, $\mathrm{p}$-value $=)$. In the religious school this association occurred in the lowest proportion of indications of the submissive, mixed submissive and aggressive and assertive categories by sixth graders, and a higher indication of the aggressive strategy by seventh grade students. In the lay school, there was a greater indication of the submissive and aggressive mixed strategy by fifth grade students, while sixth grade students indicated, more than the others, the submissive and assertive and aggressive mixed strategy. In summary, the reported analyzes show that more coping strategies, especially violent ones, are found in the religious school than in the lay school.

\section{Granting forgiveness and conceptions about the act}

As for the experience of forgiving, it was found that a slightly larger proportion of students in the lay school than in the religious school $(93 \%$ and $89 \%$ 
respectively) have already forgiven someone. The experience with retaliation or revenge was much less admitted by very similar contingents of the two schools (41\% religious school and $44 \%$ lay school). Among those who reported having already forgiven in the lay school, the majority were male $(61 \%)$, and almost half $(48 \%)$ female. In the religious school, the reverse happened, but in a more balanced way, since $52 \%$ of the female students reported have forgiven someone, which was reported by $47 \%$ of male students. As for what would have happened to the granting of forgiveness, it was found that the majority $(57 \%)$ of the participants, mainly female students of the religious school and male students of the lay school reported having fought or been offended by a person who was later pardoned. One-third of the sample, made up mainly of female students from the two schools, revealed that they had forgiven because there was no intention in the act committed, or had perceived regret in the other party. Much smaller contingents interpreted the response as a result of the fact that they had forgiven and thus reported having reconciliated $(13 \%)$ with the offender.

Concerning the difference between male students and female students about the perpetration of retaliation or revenge, it was found that $60 \%$ of those who reported having already done so in the lay school were male. In the religious school, it was found that this trend reverses, in a reduced form, since among those who reported having taken their revenge, 53\% were female and $46 \%$ male. In short, participants who report to forgive more frequently are also those who also reported they took revenge more often, in this case, female students of the religious school and male students of the lay school.

It was found that the majority (64\%) of the participants would forgive someone who excluded them from a party, insulted them (63\%), damaged property $(61 \%)$, and excluded them from a group activity $(60 \%)$. The following offenses would not be forgiven by the great majority: exposure to public ridicule $(79 \%)$ and false accusation (69\%). Physical aggression would also not be forgiven, but by a contingent not much higher $(57 \%)$ than $(43 \%)$, who would forgive. Except for the situation of having property damaged by someone, in which the contingent of participants who would forgive the offense would be $7 \%$ higher in the religious school than in the lay one, the other differences between the schools in the willingness to forgive did not exceed 5\%. In most situations (being blamed for noncompliance, being mocked publicly, insulted), the
$1 \%$ difference in the greater willingness to forgive was found in the lay school.

There was a significant difference between the sexes in the value of forgiving to make a good impression, considered more pertinent to males ( $\mathrm{x} 2=6,124 \mathrm{~b}$, $\mathrm{df}=1, \mathrm{p}$-value $=0,013)$. There was still a difference in the greater tendency of males not to apologize for manifesting anger unjustifiably, as well as for perpetrating physical aggression motivated by anger. However, it was found that, again, some differences found between the sexes are associated with the type of school, since according to the chi-square test a significant association of this type was found in the refusal to forgive false accusation, since a significantly larger contingent of female students from the lay school reported they would not forgive such offense $(\mathrm{x} 2=3.754 \mathrm{~b}$, $\mathrm{df}=1$, $\mathrm{p}$-value $=0.053)$. There was also a significant difference between males and females in accepting to publicly expose a friend's mistake after forgiveness, where a larger proportion of female students of the lay school disagreed that they would do so $(\mathrm{x} 2=3699 \mathrm{~b}$, df $=1$, $\mathrm{p}$-value $=0.054)$. Another sex-school association was found in relation to the significantly higher proportion of female students of the lay school in agreeing with the possibility of disclosure of the authorship of the damage suffered $(\mathrm{x} 2=4.187 \mathrm{c}, \mathrm{df}=1$, $\mathrm{p}$-value $=$ 0.0410). Also associated to school was the difference between the sexes in the greater disagreement between male students of the lay school over the possibility of returning a physical aggression than female students $(\mathrm{x} 2=13,343 \mathrm{c}, \mathrm{df}=1, \mathrm{p}$-value $=0,000)$. In summary, the willingness of participants to forgive focuses on less serious offenses such as material damage or exclusion than on physical assault and false accusation, with differences between male students and female students, since the latter from the lay school were less likely to forgive false accusations and presented a greater tendency to retaliate, disclosing the authorship of the damage suffered and returning physical aggression.

Regarding the reactions caused by an offense, it was verified that the majority $(63 \%)$ of the sample reported that they would not continue to feed negative feelings towards the aggressor and would not cause him to suffer consequences, such as: publicizing the offense committed $(60 \%$ would not reveal the offense to the teacher and $77 \%$ would not disclose to anyone). The desire to retaliate after suffering physical aggression was admitted by most of the participants $(65.7 \%)$. In addition, the distancing due to an offense was admitted as true by most of them (81\%), who also consider 
that it is easier to forgive a friend (63\%), which can also occur when one understands the reason of the aggressor $(75 \%)$. Forgiving because it is the right thing to do was approved by a large majority $(80 \%)$ of participants, but not to be considered positively by others (42\% agreement versus $57 \%$ disagreement). The differences between schools were greater in these issues, with a difference of $13 \%$ more concordances in the religious school on the duty to forgive for having been taught as the correct thing to do, as well as a greater tendency $(11 \%)$ to forgive someone close. On the other hand, the participants of this school showed a lower tendency $(11 \%)$ to disclose offenses like having property damaged, than those of the lay school, that is, less propensity to retaliate in this situation. In other questions, the differences between schools did not exceed $5 \%$. In sum, there are few differences between schools, focused on the reasons for forgiving, which would be closeness and obedience to the guidelines given, most valued in the religious school. The sample also showed a willingness to overcome the offense, except for the desire to distancing, because of the offense, and to retaliate after physical aggression.

Concerning frequency with which the participants would or would not make the offender suffer certain consequences, 90\% admitted that there would often be a possibility of reconciliation with the offender in terms of re-establishing a dialogue, with no differences in above $4 \%$ between the two schools. In the same line of overcoming what occurred, a large majority $(80 \%)$ reported that it would be very likely to maintain positive feelings towards the offender. Almost threequarters of the sample $(69 \%)$ would rarely or never consider the offender to be in debt, as reported by $65 \%$ that they could understand (often or always) the offender's motives, half of which $(50 \%)$ might even forget the fact. On the other hand, more than half $(81 \%)$ admitted that they would expect the perpetrator not to repeat the offense committed. There were no significant differences between schools, except for the greater willingness $(11 \%)$ of the religious school students to never forget the offense suffered and the greater willingness $(9 \%)$ to understand the motivation of the offender in the lay school. In summary, there was again a tendency to overcome the problem, with few differences between schools, which consisted of a greater tendency to overcome it in the lay school than in the religious school.

Regarding the expectation of receiving forgiveness after some offense, it was verified that the great majority
$(92 \%)$ would expect this outcome when there was an attempt to compensate, a lack of intention $(86 \%)$; or when they had been defended by friends ( $86 \%$ ). They would also wait for the moment when there was a manifestation of repentance $(85 \%)$, when the damage had not been significant $(70 \%)$, or even when some time had already elapsed after the offense (66\%). However, if the offense had been motivated by the desire to fight back some previous aggression, more than half $(60 \%)$ would not have expected to be forgiven by the victim.

The schools only differed in the expectation of forgiveness after the manifestation of repentance, which was $9 \%$ higher in the religious school. In relation to the expectation of being forgiven, an association between sex and the type of school was found again in the following situations: greater expectation of forgiveness among the female students of the lay school for having caused unintentional damage $(\mathrm{x} 2=4,347 \mathrm{c}$, df $=$ 1 , -value $=0.037)$. Among male students of this same school, there was an association between expectation of forgiveness when they had been defended by friends $(\mathrm{x} 2=3582 \mathrm{c}, \mathrm{df}=1, \mathrm{p}$-value $=0.049)$, and a tendency to association when the damage had not been significant $(\mathrm{x} 2=3.458 \mathrm{c}, \mathrm{df}=1, \mathrm{p}$-value $=0.073)$. The same tendency, the expectation of forgiveness, was found among female students of the religious school, if regret had been expressed $(\mathrm{x} 2=3.785 \mathrm{~b}, \mathrm{df}=1$, $\mathrm{p}$-value $=$ 0.078). In short, data on the expectation of receiving forgiveness after committing an offense relate to the absence of intent, to the importance of harm and to repair attempt, more frequent in the lay school, while manifestation of repentance was more frequent in the religious school.

Regarding the possibility of asking for forgiveness and, in which situations, it was verified that the great majority $(75 \%)$ of the participants reported willingness to apologize. An even larger contingent (94\%) reported that they would do so when the offense had been committed unintentionally, when injury had been inflicted (92\%) upon someone's belongings, when they felt regret $(91 \%)$, when they had shown somebody unfair anger (88\%), when there had been a bond of kinship or friendship with the victim $(79 \%)$, when they had committed physical aggression motivated by rage $(76 \%)$, or when they had forgotten to invite a person to a party $(74 \%)$. There were no significant differences between schools, except for the lesser disposition of the religious school students to apologize than of those of the lay school, with a difference of $5 \%$. In short, it turns out that willingness to ask for forgiveness relates 
to intentionality, perpetration of harm, or injustice and closeness to the victim.

It is important to observe that significant associations were found between the type of school and the reaction after suffering an offense, as well as between the type of school and reasons to forgive (a) in 3 situations. In relation to the reaction after suffering an offense, there was an association between being a student of a religious school and the disposition to leave after the offense $(\mathrm{x} 2=7.438 \mathrm{~b}, \mathrm{~d}=1$, $\mathrm{p}$-value $=0.048)$. There was also an association between being a student of this type of school and the willingness to forgive because it had been taught as the right attitude to take $(\mathrm{x} 2=8.064 \mathrm{~b}, \mathrm{df}=1, \mathrm{p}$-value $=0.053)$. Regarding the greater ease of forgiving friends than other people, there was a significant association with attending a lay school ( $\mathrm{x} 2=3,738 \mathrm{~b}, \mathrm{df}=1$, p-value $=0,053)$.

To complete the data analysis, the relationship between pardon granting and the resolution strategy was verified by comparing those that predominated in the conflicts, which involved the same offenses described in the situations evaluated by the participants as forgivable or not. We thus verified that four situations would be forgiven, three of which would probably be solved through submission, since this was the predominant reaction of the sample to solve the similar conflicts described in the open questionnaire, involving the same impasses or aggressions. They were exclusion, whose proportion of submission was 37\% and suffering insult, whose proportion of the same type of responses was $25 \%$. The damage inflicted to property would also be forgiven by most of them $(61 \%)$, but in the analogous conflict which involved this type of damage, the damaged book, aggression was the most frequent strategy $(45.6 \%)$. The following offenses would not be forgiven by most of the students: holding the participant accountable for a non-committed offense $(68.7 \%)$ consistent with the reaction to the conflict of threat of punishment for the mess, in which the mixed tendency of aggression and submission predominated, (50,7\%, equal in the 2 schools), and exposure to public mockery $(79 \%)$, in which submission had the highest frequency $(25.5 \%)$ considering the sample as a whole, but which differed between schools in terms of predominance, overcome by aggression $(27 \%)$ in the religious school, and by the assertive strategy $(26 \%)$ in the lay school, where it was higher than submission $(24.8 \%)$. Physical aggression would also not be forgiven by a contingent $(57 \%)$ larger than those who would forgive it that totaled $43 \%$. Except for the situation of having a belonging damaged by someone, in which the contingent of the participants who would forgive the offense would be $7 \%$ higher in the religious school than in the lay one, the other differences between the schools regarding willingness to forgive did not exceed $5 \%$ (suffering physical aggression, being the only person not invited to a party, being barred from participating in a group). In most situations (being held liable for a noncommitted fault, being mocked publicly, being insulted) the $1 \%$ difference in the greater willingness to forgive was found in the lay school. In summary, none of the situations evaluated as forgivable by most of the participants was solved through conciliation in the analogues in the open questionnaire. On the contrary, most would not be faced, or would be confronted in a violent way, not differing from situations that would not be forgiven.

\section{Discussion}

Considering the results found, which emphasized the absence of a relationship among willingness to forgive, type of conception about the act and the use of certain strategies, it has been verified that the hypotheses that were raised about these relations, although in an exploratory manner, were not confirmed. Nor have been confirmed the ones related to the relationship between personal characteristics such as sex and religion and willingness to forgive.

As it was pointed out in the conclusion placed at the end of the results section, it was verified that none of the situations evaluated by the participants as forgivable was solved by conciliation in their analogues described in the open questionnaire. It was also verified that the sample resembled other samples studied in previous surveys (Leme, 2004, Leme, 2006, Leme, Carvalho and Joveleviths, 2012, Leme and Carvalho, 2014), due to the prevalence of the less adequate strategies to solve conflicts peacefully, namely: submissive, mixed of submissive and aggressive, and aggressive. It is worth mentioning that the participants of the present study also resembled those of the previous studies (Leme, 2004, Leme, 2006, Leme, Carvalho and Joveleviths, 2012, Leme and Carvalho, 2014), in situations where each type of strategy was more frequent, in this case, submission in the conflict of public humiliation, exclusion of a game and being criticized by a colleague. In the case of the situations of the damaged book returned, and the push in the queue prevailed the aggression, also verified in previous studies (Leme, 2004; Leme, 2006; Leme \& Carvalho, 2012). Conciliation was chosen more often in the case of being 
hit by a small child with a ball, receiving a colleague's criticism, being excluded of a game, having a request refused, and suffering banning of a TV show by parents. Thus, the more prevalent use of less conciliatory strategies indicates that willingness to forgive is probably absent in the resolving of their conflicts.

Besides, as in previous studies (Leme, 2004, Leme, 2006, Leme, Carvalho and Joveleviths, 2012, Leme and Carvalho, 2014), the differences found were related to the type of establishment attended by the participant, which in previous studies consisted of the public or private nature of the institutions. Specifying what the differences consisted of, it was found a greater tendency of public school students to use submissive, aggressive, and mixed strategies of aggression and submission, whereas private institution students relied more on submissive and assertive strategies than on the latter two. In the present study, there was a significant difference between the two types of educational institutions, religious and lay, observing as highlighted in the analysis of the results among the students of the second school a greater use of strategies of peaceful confrontation and non-confrontation, while among those of the first school, it was observed more coping strategies, including violent, as aggression, not found in the first school in the same situations. The difference in the socioeconomic level among students of both types of school may be a possible explanation for such differences, for as Moreira, Abreu and Rique (2012) report, studies have found that parents of a less affluent socioeconomic level would be more concerned about meeting economic needs, tending to exercise more authority and explaining the consequences of acts less. Parents of a more affluent socioeconomic level would be more concerned about the development of their children, encouraging them to reflect on the consequences of their own actions. In the case of the schools in the present study, even though both were private, we observed, as highlighted in the sample description, differences in the socioeconomic status between the two of them. In this sense, the similarities verified between the lay school of this research and the previously studied private ones regarding the third choice of more peaceful and conciliatory strategies, may be associated with the similarities of the socioeconomic level of the students. Likewise, the religious school, whose socioeconomic level proved to be less affluent, resembled the public school in the greater use of strategies of avoidance of conflict or aggressive confrontation, or even of mixed submission and aggression.
Different from previous studies (Leme, Carvalho and Joveleviths, 2012, Leme and Carvalho, 2014), were the results we found indicating the existence of associations in the grades studied and the type of resolution strategy reported, as well as sex. It is worth mentioning that Ozguluk and Baker (2010), who used the conflict resolution scale developed by Deluty (1979), in its closed version in alternatives found differences between 4 th and 7 th grade students. In the present study, also unlike the previous ones (Leme, 2004, Leme, 2006), no significant differences were found between genders. It was verified that the differences between sexes were associated to the type of school attended, the use of aggressive and submissive strategies by female students of the religious school being more frequent, whereas the ones of lay school tended more to use assertive strategies or a mix of submission and aggression or of assertive and submissive strategies. However, the male students of the 2 schools in the present study differed less among themselves, since the differences found were restricted to the greater use of the aggressive and the mixed aggressive and submissive strategies in the lay school. The differential impact of the type of school, religious or lay, and socioeconomic level on each sex is an issue to be investigated in future studies, once we have not found reference in the literature in this regard.

Regarding the participants' willingness to forgive, it was verified that the occurrence of forgiveness is more likely after minor offenses, occurring differences between male and female students, since those female students of the lay school were less likely to do so in the event of false accusation; also, they showed a greater tendency to retaliate, telling who the offender was, and returning physical aggression. It is interesting to remember that male students of the same school reported more experience in forgiving than other participants, which perhaps explains the greater probability of their practicing such an act, more than the others. In this sense, the hypothesis based on the literature that would be found more females willing to forgive was not confirmed, and was not found in the religious school.

On the other hand, there were few differences among schools regarding reasons to forgive, probably because they consisted of what the research identified as being associated with the granting of pardon, in the case, proximity between victim and offender, the understanding of the motive and obedience to guidance to forgive, more frequent in religious school, confirming what was pointed out by Gouveia et al. (2009) on the importance of religion for forgiveness, due to its value in this institution. 
Reactions after the granting of forgiveness, as a substitution of negative feelings for positive ones, forgetting the occurrence, as well as the reasons to forgive, show conceptions of the act that are consistent with what was identified by the research as relevant, indicating the experience of the participants (Fehr et al. (Abreu et al., 2011).

However, the hypothesis that the relationship between the adequate concept forgiveness and a greater tendency to use strategies favorable to the good resolution of the conflict was not confirmed. This is because the observed desire for withdrawal exhibited by the sample as well as the desire to retaliate after physical aggression seem to confirm what Barnes, Brown, and Osterman (2009) observed regarding the possible meaning of the absence of reaction, in this research categorized as submission to solve analog conflicts. In other words, it is likely that the lack of reaction in these cases confirms the desire for retaliation resulting in the interruption of the relationship manifested in some of the conflicting situations, not confirming the hypothesis of a relationship between the adequacy of the conception of forgiveness and the use of appropriate strategies for conciliation.

The data on the expectation of being forgiven after committing an offense also indicate that the participants conceptualize the granting of forgiveness according to what has already been identified as relevant by the investigations for its occurrence, such as lack of intention, irrelevance of the damage and attempt to repair (Fehr et al., 2010, Struthers et al., 2008). These conceptions were more frequent in the lay school, while in the religious school the manifestations of repentance were more frequent, which is consistent with what is advocated by the Catholic religion. Coherently with what was found in the expectation of receiving pardon for a fault, it turns out that the willingness to ask for forgiveness is related to the lack of intentionality, perpetration of harm, or injustice, and proximity to the victim. On the other hand, the associations found between sex and type of school, indicating different attitudes regarding the granting of forgiveness also remain as questions to be investigated in future studies, since no studies were found to provide information in this regard. It is important to remember that although they are aware of what is important for the occurrence of pardon, none of the situations evaluated as forgivable by the majority of the participants was solved through conciliation in the same situations contained in the open questionnaire. Most would not be faced, or would be confronted in a violent way, not differing from situations that would not be forgiven.

Thus, the conclusion that the research favors is that among pre-adolescents with similar characteristics to those of the sample of this study, conflict resolution and forgiveness are not yet related, since submission, the predominant reaction of the sample in situations may have other meanings, for example, lack of knowledge about how to act in the situation of conflict, or even a desire for retaliation through distancing. In addition, it was found that situations judged by the majority as forgivable would be solved through coercion or aggression, incompatible with forgiveness, because they tend to lead to impasses, making conflict resolution and pardon difficult. It is possible that as it develops, this relationship: forgiveness, conciliatory resolution can be achieved, since Flanagan, Hoek, Ranter and Reich (2012) verified this relationship in adolescents between 11 and 14 years old, mainly female. However, it is worth mentioning that the strategies of resolution were presented in alternatives, unlike the present study, which requested an answer to the open question about what the participants would do in that situation, which is closer to the situations experienced in the conflicts of daily life.

The present study presented as limitation the restriction of the convenience sample to private schools because of its objective to investigate the influence of the participants' religion on their tendency to forgive, as well as their conceptions of forgiveness. The sampled diversity that would be possible through the inclusion of students from public schools was, thus, limited, because those institutions cannot profess any religion by force of law. On the other hand, comparing a private school with a public school would limit the difference in the socioeconomic level of the students, which, in previous studies (Leme, 2004, Leme, 2006, Leme, Carvalho and Joveleviths, 2012, Leme and Carvalho, 2014), have proved to be an important variable in interpersonal conflict resolution. However, it is worth remembering that the socioeconomic level of the lay school students was more affluent than the students of the religious school, which was even postulated as a possible explanation for some differences found between the two schools.

Another limitation lies in the instruments used to evaluate participants' conceptions on forgiveness. Since no instruments were found to make this evaluation, it was decided to create questions that approached the conceptions, which together with the limitation of 
the sample, gave an exploratory character to the present research. Besides, the issues of forgiveness closed in alternatives may have induced more appropriate conceptions to what is socially valued.

Directions for future studies were pointed out, especially research in other contexts about the influence of the type of school attended by students of each sex, which was manifested in differences among female students of the two schools, while the male students appeared to be more similar to each other. Another question to be investigated is to verify if the difference found between the two private schools in this study is maintained in other studies, which could be verified by varying the socioeconomic level of religious schools or by comparing schools of the same socioeconomic level, but different in their nature, religious or lay schools. Finally, to investigate whether the relationship between forgiveness and progress in development pointed out by Flanagan et al. (2012) will be found in our environment.

\section{References}

Abreu, E.L., Moreira, P.L. \& Rique, J. (2011). O pensamento moral do perdão na criança Psicologia Argumento, 29, 65, 249-258. Recuperado em www. pucpr.br/psicologiaargumento

Barnes, D, Brown, R.P. \& Osterman, L.L. (2009). Protection, payback or both? Emotional and motivational mechanisms underlying avoidance by victims of transgression. Motivation and Emotion, 33, 400-411. doi: 10.1007/s11031-009-9142-4

Baneerjee, R., Benett, M. \& Luke, N. (2010). Children's reasoning about the self presentational consequences of apologies and excuses following rule violations. British Journal of Developmental Psychology, 28, 799-815. doi:10.1348/0261510009X479475

Blanchette, I. (2014). Does emotion affect reasoning? Yes, in multiple ways. In. I. Blanchette (ed.), Emotion and reasoning (pp. 1-21). New York: Psychology Press.

Bergeron, N. \& Schneider, B.H. (2005). Explaining cross-national differences in peer-directed aggression. A quantitative synthesis. Aggressive Behavior, 31 2, 116-137. doi:10.1016/j.paid.2010.10.031

Davis, J.R. \& Gold, G.J. (2011). An examination of emotional empathy, attributions of stability, and the link between perceived remorse and forgiveness.
Personality and Individual Differences, 50, 392-397. doi:10.1037/a0019993

Deluty, R.H. (1979). The children's action tendency scale: a self report measure of aggressiveness, assertiveness and submissiveness in children. Journal of Consulting Psychology, 47, 1061-1071.

Eaton, J. \& Struthers, C.W. (2006). The reduction of psychological aggression across varied interpersonal contexts through repentance and forgiveness. Aggressive Behavior, 32, 195-206. doi:10.1002/ab

Enright, R.D. (2002). Forgiveness is a choice. A step by process for resolving anger and restoring hope. Washington, APA Life Tools.

Fehr, R., Gelfand, M.J. \& Monisha Nag (2010). The road to forgiveness: A meta-analytic synthesis of its situational and dispositional correlates. Psychological Bulletin, 136 5, 894-914. doi: 10.1037/a0019993

Flanagan, K.S., Hoek, K.K.,Ranter,J.M.\& Reich,H.A. (2012). The potential of forgiveness as response for coping with negative peer experiences. Journal of Adolescence 35, 1215-1223. doi:10.1016/j. adolescence.2012.04.004

Gouveia, V.V., Costa, J. M., Araújo, L.B.U., Gouveia, R.S.V., Medeiros, E.D. \& Gonçalves, M.P. (2009). Disposição para perdoar, desejabilidade social e religião: um estudo correlacional. Revista Bioética, 17, 319-334. Recuperado em: revistabioetica.cfm.org. br

Leme, M.I.S.L.(2004).Resolução de conflitos interpessoais: interação entre cognição e afetividade na cultura. Psicologia Reflexão e Crítica, 17, 3, 367380. Recuperado http://www.scielo.br/pdf/prc/ vol17n3.

Leme, M.I.S.L. (2006). Cognição, Cultura e Afetividade em solução de problemas:estrutura e função. (Tese de livredocência não publicada). Instituto de Psicologia da Universidade de São Paulo, São Paulo.

Leme, M.I.S.L., Carvalho, A.M. \& Joveleviths, I. (2012). Opinião dos pais e resolução de conflitos por préadolescentes. Temas em Psicologia, 20, 337-354. doi: 10.9788./TP2012.2-05

Leme, M.I.S.L., \& Carvalho, A.M. (2012). Opinião dos professores e resolução de conflitos por pré-adolescentes. Nuances:estudos sobre educação, 23, 55-77. Recuperado em: http://revista.fct.unesp. $\mathrm{br} /$ nuances/issue/23. 
Leunissen, J.M., Cremer, D.D., Folmer, C.P.R. \& Van Djike, M. (2013). The apology mismatch: asymmetries between victim's need for apologies and perpetrator's willingness to apologize. Journal of Experimental Social Psychology, 49, 315-324. Recuperado em: http://dx.doi.org/10.1016/j.esp.2012.12.005

Mc Cullough, M. E., Pargament, K.I. \& Thorensen, C.E. (2000). Forgiveness: theory, research and practice. New York, The Guilford Press.

Macedo,L.S.R. \& Sperb, T.M. (2013). Regulação de Emoções na Pré-Adolescência e Influência da conversação familiar. Psicologia:Teoria e Pesquisa, 29, 2, $133-140$

Moreira, P.A., Abreu, E.L. \& Rique, J. (2012). Influência da idade, contexto socioeconômico na compreensão emocional de crianças. Estudos de Psicologia, 29, 761s-767s. Recuperado em: periodicos.puccampinas.edu.br/seer/index.php/estudos

Ozgulluk, S.B. \& Baker O, E. (2010). Gender and grade differences in children's alternative solutions to interpersonal conflict situations. Procedia Social and Behavioral Sciences 5, 511-514. Doi:10.1016/j. sbspro.2010.07.134

Posada, R. \& Parales, C.J. (2012). Violencia e desarrollo social: mas allá de una perspectiva de trauma. Universitas Psychologia 11 (1), 255-267. Recuperado em universitaspsychologica.javeriana.edu.co
Rizkalla, L., Wertheim, E.H. \& Hodgson, L.K. (2008). The roles of emotion management and perspective taking in individuals' conflict management styles and disposition to forgive. Journal of $R e-$ search in Personality., 42, 1594-1601. doi:10.1016/j. rp.2008.07.014

Rodrigues, M.C., Dias, J.P. \& Freitas, M.R.F.L.(2010). Resolução de conflitos interpessoais: promovendo o desenvolvimento sociocognitivo na escola. Psicologia em Estudo,Maringá,15, 4,831-839. doi.org/10.1590/S1413-73722010000400019

Santana, R.G. \& Lopes R.F.F. (2012). Aspectos conceituais do perdão em Psicologia. Psicologia: Ciência e Profissão. 32 (3),618-632. site.cfp. org.be>publicações

Schleien, S., Ross, H. \& Ross, M. (2010). Young children's apologies to their siblings. Social Development, 19, 1, 170-186. doi:10.1111/j.1467-9507.2008.00526.x

Struthers, C.W., Eaton, J., Santelli, A.G. \& Uchiyama, M. (2008). The effects of attributions of intent and apology on forgiveness: When saying sorry may not help the story. Journal of Experimental Social Psychology, 44, 983-992. doi:10.1016/j.esp.2008.02.006

Recebido em: 09/08/2016

Reformulado em: 14/08/2017 Aprovado em: 10/11/2017 
Sobre as autoras:

Maria Isabel da Silva Leme is full professor at the Institute of Psychology at the University of São Paulo where she researches learning processes and their transfer through the resolution of academic and social problems, such as interpersonal conflict.

E-mail: belleme@usp.br

ORCID: 0000-0003-0844-3554

Laura Carrasqueira Bechara is a psychologist graduated a the University of São Paulo (2012/2016) and a CAPES scholarship holder in the Master's Program in Clinical Psychology at the same institute, where she's studying Psychoanalysis, Resentment and Twins. Received a scholarship for Scientific Iniciation from Nacional Council of Research to participate to this research.

E-mail: lauracbechara@gmail.com

ORCID: 0000-0002-6397-6508.

Mariana Kfouri is graduated in Psychology at Psychology Institute at Universidade de São Paulo. Received a scholarship for Scientific Iniciation from Nacional Council of Research to participate to this research. Colaborated on data collection and processing.

E-mail: marianaokfouri@hotmail.com

ORCID: 0000-0002-0842-3716

Contato com as autoras:

Instituto de Psicologia da Universidade de São Paulo

Av. Professor Mello Moraes, 1721

São Paulo-SP, Brasil

CEP: 05508-900 